\title{
Determinants Analysis of SMEs Sustainable Competitive Advantage in Go Digital Efforts in Buleleng Regency
}

\author{
Gede Adi Yuniarta ${ }^{1, *}$ I Gusti Ayu Purnamawati ${ }^{1}$ I Putu Gede Diatmika ${ }^{1}$ \\ ${ }^{1}$ Department of Economic and Accounting, Universitas Pendidikan Ganesha, Singaraja, Indonesia \\ ${ }^{*}$ Corresponding author. Email: gdadi_ak@yahoo.co.id
}

\begin{abstract}
MSME business actors in Buleleng Regency often experience problems including resource capacity, financing, financial management knowledge, innovation, technology and other issues that hinder their development. The Covid-19 pandemic indirectly invites the public to apply technology in business activities and at the same time supports the Buleleng Regency government program through going digital. This study aims to analyze the variables that influence the sustainable competitive advantage of SMEs in the Buleleng Regency. These variables include financial literacy, access to capital, interest in using e-commerce, and innovation. Through testing these variables, the causes can be analyzed. The independent variables in this study consist of financial literacy, access to capital, interest in using ecommerce, and innovation. At the same time, the dependent variable is a sustainable competitive advantage-data collection through observation and interview methods. The research subjects were MSME actors in Buleleng Regency by determining the sample using probability sampling. Data analysis using multiple linear regression analysis. The results showed that the variables of financial literacy, interest in using e-commerce, innovation and access to capital showed a positive and significant influence on the performance of MSMEs to go digital in Buleleng Regency.
\end{abstract}

Keywords: Competitive, Determinant, Excellence, Sustainable, MSME.

\section{INTRODUCTION}

The private sector is currently experiencing quite rapid development in various countries around the world. Of course, it poses a big challenge to business actors due to the current fluctuating economic conditions due to the Covid-19 Pandemic and global competition. The role of MSMEs is very important in promoting development recovery and contributing to the re-growth of the Indonesian economy. If we look back at 2008, Indonesia experienced an economic crisis and then could bounce back, even increasing. The contribution given by the MSME sector was mainly in increasing GDP, wherein 2009-2013 MSMEs contributed 57.6\% with an average growth of $6.7 \%$. This percentage shows that MSMEs contribute greatly to micro-enterprises by $49.6 \%$ [1].

The increase in the number of MSMEs in Indonesia continues to progress. In 2015, the number of MSMEs had reached 60.7 million units with an increase in the composition of micro-enterprises by $98.73 \%$ with an average growth in 2011-2015 of 2.4\%. Behind its development, the number of MSMEs that continues to increase is also balanced by their very large contribution to the country's economy, so it is expected that it will significantly impact the Indonesian economy [1]. The development of MSMEs can be said to have developed quite rapidly; this can be seen from the number of MSME business actors growing in the Buleleng Regency. This growth has not been accompanied by increased human resource competence, competitive financing, innovation, management modernization, macroeconomic stability, and adaptation to the global value chain [2].

MSMEs continued to increase from 2015-2018. The increase can be quite significant, wherein in 2015, the number of MSMEs in Buleleng Regency was 30,145 units. In 2016 increased to 31,340 units; 2017 also experienced an increase from the previous year as many as 1,567 units to 31,907 ; in 2018 , there was also an increase of 2,645 units.

However, from another point of view, MSME business actors in Buleleng Regency often experience problems including resource capacity, financing, financial management knowledge, innovation, 
technology and other issues that can cause and hinder the development of MSMEs themselves. The phenomenon of the problems behind the increase in the number of MSMEs in Buleleng Regency, especially those that arise in MSMEs in Buleleng District, as it is known that MSMEs are Buleleng District have also experienced a drastic increase and have the highest number of MSMEs in Buleleng Regency.

The number of MSME business actors who have not experienced an increase in developing their business can mostly be said to be just walking in place. The absence of this increase is supported by data from the Central Statistics Agency of Bali Province; based on this data, MSMEs in Buleleng Regency have poor business prospects of 5,231 units compared to other regencies in Bali Province in 2018, and then followed by the lowest Regency, namely Klungkung Regency. as many as 614 units. However, MSMEs in Buleleng Regency have the largest number of business prospects compared to other regencies. Buleleng Regency has several 5,231 MSMEs with poor business prospects, most of which are in Buleleng District, most of the MSMEs in Buleleng District have poor business prospects. They have a very large number of MSMEs in 2018, as many as 6,600 [3].

The aspect of capital is one of the main causes that hinder the development of MSMEs in Buleleng Regency; these problems can hamper business operational activities, where most MSMEs experience obstacles in expanding their business and even some business actors are unable to continue their business due to capital problems. Several factors that cause or hinder the performance of MSMEs in the Buleleng Regency and capital problems are due to lack of financial literacy. Financial literacy is one of the concepts of economic knowledge, which includes skills, awareness, and understanding related to financial knowledge, such as managing and planning financially well [4].

Most of the problems regarding financial literacy in MSME businesses, especially in micro and small businesses, do not know or do not understand financial literacy in managing finances. Based on the results of a survey conducted by the National Financial Literacy Indonesia stated that in 2019 the level of financial literacy had still not reached the set target of $75 \%$, while in 2019 , the percentage of financial literacy itself had only got $38 \%$ on a national scale [5]. The level of financial literacy based on regional strata such as rural and urban areas is also still very far from the financial literacy target that has been set; at the village level alone, the percentage of financial literacy that has just been achieved is $34.35 \%$, this figure is below the financial literacy index at the urban level which is $41,41 \%$ [6]. The story of financial literacy in MSME business actors in Bali has only touched $38 \%$ so that the low percentage level of financial literacy will ultimately affect the performance of MSMEs themselves so that it can be said that the goals of their business may not be achieved as expected.

Financial literacy or financial management in MSME business actors in Buleleng Regency occurs because MSME business actors have not managed their finances systematically; in general, these business actors mix personal finances with business finances. Most of them do not have the knowledge and skills to work financial resources properly. If it continues to be carried out by MSME business actors, MSME financial management will not run well and impact performance. The run business does not see an increase because it cannot separate between personal finance and business finance. Understanding literacy is very necessary so that business actors are not wrong in making decisions on financial management; lack of understanding of financial literacy will also impact finances and business sustainability. The next problem that affects the performance of MSMEs is access to capital; access to capital is the thing that most often becomes an obstacle for MSME business actors. The problem of access to financing is a problem that still occurs in MSME business actors; even from the results of a survey conducted by the OJK, $70 \%$ of the total 60 million MSMEs have problems with access to financing; this is due to several obstacles faced by business actors such as administrative constraints. And other barriers that make it difficult for MSME business actors to get access to financing.

Considering a large number of MSMEs in Buleleng Regency, which is proportional to the many obstacles faced by MSME business actors, one of which is the problem of access to capital, the solution provided by the Buleleng Regency government itself is to provide People's Business Credit to 35,552 MSME actors in each sub-district in Buleleng Regency. Buleleng Regency, but from the total number of existing MSMEs, only 19,000 MSMEs can only be touched by this access to capital, while the rest have not been able to access it. Many MSME actors cannot fulfil the administrative requirements and procedures requested by financial institutions, so most MSME actors then use and rely on their capital.

Research conducted by [7] states that access to financing is indeed difficult for MSME actors to access, which will be an obstacle to the growth and development of MSMEs. This is because formal institutions such as banks are still hesitant to provide credit to MSME actors, in addition. After all, the profits received from them are not as much as the profits from large entrepreneurs. This makes it increasingly difficult to access capital for MSME business actors to obtain credit loans from formal institutions. Many business actors only depend on business financing, which will impact the performance of these MSMEs. The last problem related to the performance of MSMEs in the Buleleng Regency is the problem of the interest of MSME business actors in using 
e-commerce. Technology is a necessity that cannot be avoided and is very important in this day and age. In addition, technology has a role in helping and developing a business, one of which can help business actors is ecommerce which is an electronic business mechanism.

Go digital is one of the efforts of the Buleleng district government to improve the competitive performance of MSMEs. It has become a current demand for MSME actors to use technology in marketing, sales, or developing their business. The interest of MSME business actors in Buleleng Regency in using technology such as e-commerce is still very minimal. Whereas the use of technology, especially e-commerce, can affect marketing, operating, and financial performance. Based on data from the Bali Province Central Statistics Agency from 464,787, the number of MSMEs in the Bali Province, business actors such as MSMEs that use the internet are only 52,015 units; the rest do not use the internet in developing their business. Based on the average, business actors who use the internet in their business development are 14,000 units in Denpasar City. In Buleleng Regency, out of a total of 59,000 MSMEs from 2010-2018, business actors using the internet were only 4,184 units [8].

Business actors must continue to innovate to survive in a dynamic environment. Thus, innovation is a key factor in organizational products and processes to stay in a dynamic environment and technological change[9]. In addition, innovation is the main source for achieving competitive advantage and plays an important role in economic development [10]. Proves that the cooperation strategy built between manufacturers and distributors will positively affect the company's competitive advantage [11]. The results obtained are in line with the results of previous studies [12].

Based on the phenomenon of the problems that have been described, research on competitive advantage in achieving MSME performance has been carried out by researchers in the economic field. However, there are still some gaps in previous research. Stated that training, trust, cooperative behaviour, and innovation positively and significantly impact Sustainable Competitive Advantage [13]. That financial literacy, HR competence and business capital do not partially affect the competitive advantage of MSMEs [14]. That financial literacy and capital access positively impact MSMEs' financial performance [15]. With research results stating that the quality of human resources affects access to capital, access to information has a positive effect on access to capital, access to capital has a positive impact on the performance of MSMEs, the quality of human resources does not have a positive effect on the performance of MSMEs and access to information does not have a significant impact on the performance of MSMEs. MSME performance and access to capital have a major contribution to MSME performance [16].

\section{LITERATURE REVIEW}

This study uses the attribution theory, which was first started by [17] and then developed, initially created from a paper entitled "Native Theory of Action", a theory that explains the conceptual framework and a person's behaviour. Attribution theory tries to discover what causes what or what motivates a person to do anything. Attribution theory also states that when individuals observe someone's behaviour, they try to determine whether internal or external factors cause something. In this study, the theory used is attribution theory because attribution theory can explain internal and external factors that can affect competitive advantage in performance. Internal factors that can affect business performance in this study are financial literacy, interest in using e-commerce, and innovation. In contrast, external factors that can affect business performance in this study are access to capital.

[18]Framework competitiveness by Porter's explains the threat of substitute products and the bargaining power of buyers and suppliers as potential actors in achieving competitive advantage. According to [12], sustainable advantage occurs when the benefits of the uniqueness of the company's assets can withstand competitors' strategies. Thus, the values and assets that become a company's competitive advantage must be able to resist the efforts of imitation by other companies. Competitive advantage can be achieved if a company succeeds in formulating and implementing an appropriate strategy by building and jointly seeking new technological breakthroughs and competencies that can lead to the formation of a new company structure.

Financial literacy is closely related to knowledge in managing finances well; knowledge of financial management can help make good and effective decisions [19]. Managing the finances of a company is not a very easy thing because if you can't manage finances well, then it can impact the long-term finances of a company. In addition, making the right financial decisions will have an impact on the individual and the company. Financial literacy is all-encompassing knowledge of financial concepts, personal/company financial management, both personal finance and business finance [20]. Financial literacy is closely related to several skills and knowledge about finances that a person has because by having good financial knowledge, they will improve their standard of living [21].

Access to capital for MSMEs can increase economic growth. In addition to being useful for the state to stabilize the economy, access to capital can also be useful for MSMEs, namely as a source of funds that can help MSME business actors to be able to develop their businesses and as additional capital to grow. Almost all commercial banks include MSMEs in their capital schemes to expand access [22]. According to [23], access 
to capital is defined as the absence of obstacles related to administrative costs or procedures at the capital provider institutions that MSMEs feel when applying for credit. MSMEs must also have a good level of health performance because it will make it easier to access capital in financial institutions [24]. Access to capital is where businesses such as MSMEs can get loan capital to run a business, capital from formal financial institutions such as banks, cooperatives or others. In addition, there are several indicators regarding access to capital according to [15], namely (1) MSME procedures in accessing capital and (2) formal credit information; these two indicators can be used to find out how big the opportunities for MSME business actors are to access capital or get capital. From financial institutions.

According to [25], Several academic circles also agreed to define E-Commerce to improve the performance and mechanism for exchanging goods, services, information, and knowledge by utilizing network-based technology of digital equipment. ECommerce has the following characteristics: (1) there is a transaction between two parties, (2) There is an exchange of goods, services, or information; and (3) the internet is the main medium in the process or mechanism of the trade. Slaver and Narver (1994) revealed that in achieving competitive advantage, the company should pay attention to the needs of buyers at this time and pay attention to the needs of buyers in the future. Therefore, companies must anticipate by innovating and developing close relationships with buyers. Innovation as one of the variables that influence competitive advantage. This empirically strengthens the theory, which states that sustainable competitive advantage will increase if innovation increases. Innovation as a specific tool of an entrepreneur, how they exploit change into an opportunity for various fields of business and services. Innovation, according to Druker, can be a discipline, something that can be learned, and something that can be trained.

\section{RESULTS \& DISCUSSION}

This study aims to analyze the determinants of sustainable competitive advantage in MSMEs in Buleleng Regency by trying to prove a new theory constructed from previous studies by combining financial literacy, access to capital, interest in using e-commerce, and innovation towards the sustainable competitive advantage of MSMEs. The independent variables consist of financial literacy, access to capital, interest in using ecommerce, and innovation. At the same time, the dependent variables include the sustainable competitive advantage of SMEs. The study will simultaneously analyze four independent variables to prove their influence on the sustainable competitive advantage of SMEs. The population in this study were all MSME actors in Buleleng Regency. To determine the number of samples selected by using probability sampling, namely proportionate cluster random sampling, that is, if a piece of size $\mathrm{n}$ is drawn from a population of size $\mathrm{N}$ [26]. Data collection methods used in this study are: (1) Observation: a non-behavioural observation method to collect secondary data from relevant agencies, such as the number of MSME actors in the Buleleng Regency. (2) Interview: This is used to collect primary data from interviews with respondents, namely MSME actors in Buleleng Regency.

The sample in this study included 160 MSME actors in Buleleng Regency. The distribution of questionnaires using Google Forms to respondents followed the health protocol during the Covid-19 pandemic. The collection of questionnaires with a period of 1 month, and the results are presented in table 1:

Table 1. Details of Questionnaire Collection

\begin{tabular}{|c|c|c|c|}
\hline No & Questionnaire & $\begin{array}{c}\text { Number of } \\
\text { Questionnaires }\end{array}$ & Percentage \\
\hline 1 & $\begin{array}{c}\text { Number of } \\
\text { collected }\end{array}$ & 160 & $100 \%$ \\
\hline
\end{tabular}

Based on Table 1, the questionnaire was tested on 160 respondents with a percentage of $100 \%$.

Table 2. Respondent Data by Age

\begin{tabular}{|c|c|c|c|}
\hline No & Age (Years) & Amount & Percentage (\%) \\
\hline 1 & $15-30$ & 50 & 31,25 \\
\hline 2 & $31-45$ & 53 & 31,20 \\
\hline 3 & $46-60$ & 50 & 31,25 \\
\hline 4 & $61-75$ & 6 & 3,53 \\
\hline 5 & $76-90$ & 1 & 0,59 \\
\hline \multicolumn{2}{|c|}{ Total } & 160 & 100 \\
\hline
\end{tabular}

Table 2 indicates that the UMKM business actors in Buleleng District are dominated by business actors with an age range of 15-30 years and 46-60 years with a percentage of $31.25 \%$. Based on the results of the descriptive analysis, general descriptions of the research results:

1. Financial literacy data (X1) has an average value of 38.93 , which is close to its maximum value. The top score on the financial literacy variable is 50 with ten questions; most of the respondents' answers agree and strongly agree.

2. Data access to capital (X2) has an average value of 22.60. The maximum score on the variable access to capital is 30 , with five questions; this means that most of the respondents' answers agree and strongly agree.

3. Interest data using e-commerce (X3) has an average value of 18.49 . The maximum score on the variable 
of interest in using e-commerce is 25 with five questions; most of the respondents' answers agree and strongly agree.

4. The innovation data (X4) has an average value of 18.62. The maximum score on the innovation variable is 25 with five questions; most of the respondents' answers agree and strongly agree.

MSME performance data has an average value of 10.56. The maximum score on the MSME performance variable is 15 with the number of questions 3 ; most of the respondents' answers agree and strongly agree. A validity test is used to determine whether or not an instrument used in the study is valid. A device is said to be valid if r-count > r-table and vice versa. Based on the analysis, it is known that the significant values of financial literacy $\left(\mathrm{X}_{1}\right)$, access to capital $\left(\mathrm{X}_{2}\right)$, interest in using e-commerce $\left(\mathrm{X}_{3}\right)$, and innovation $\left(\mathrm{X}_{4}\right)$ have absolute residuals $>$ from 0.05 , so it can be concluded that all independent variables There are no symptoms of heteroscedasticity. Because the normality test results of the data showed normal distribution, the multicollinearity test did not show any signs of multicollinearity, and the regression model used did not have any heteroscedasticity.

This study uses multiple linear regression analysis to examine the effect of financial literacy, the results of the calculation of the constants and beta coefficients can be seen in Table 3.

Table 3. Multiple Linear Regression Analysis Test Results

\begin{tabular}{|c|c|c|c|c|}
\hline Model & $R$ & $R$ Square & $\begin{array}{c}\text { Adjusted } R \\
\text { Square }\end{array}$ & $\begin{array}{c}\text { Std. The error } \\
\text { of the Estimate }\end{array}$ \\
\hline 1 &, $649^{\mathrm{a}}$ &, 422 &, 407 & 1,878 \\
\hline
\end{tabular}

Based on the calculation of multiple linear regression in table 3 , the results of the regression equation and its interpretation are as follows:

$\mathrm{Y}=1.822+0.056 \mathrm{X}_{1}+0.171 \mathrm{X}_{2}+0.176 \mathrm{X}_{3}+0.025 \mathrm{X}_{4}$

1. The constant 1.822 shows that if the variables of financial literacy $\left(\mathrm{X}_{1}\right)$, access to capital $\left(\mathrm{X}_{2}\right)$, interest in using e-commerce $\left(\mathrm{X}_{3}\right)$, and innovation are constant, then the MSME performance variable (Y) has a positive value of 1.822 units.

2. The financial literacy variable $\left(\mathrm{X}_{1}\right)$ has a positive coefficient of 0.056 . A positive regression coefficient value indicates that financial literacy $\left(\mathrm{X}_{1}\right)$ positively affects MSME performance (Y). this illustrates that every 1 unit increase in financial literacy $\left(\mathrm{X}_{1}\right)$ can increase the performance of MSMEs (Y) by 0.056 , assuming other independent variables remain.

3. Variable access to capital $\left(\mathrm{X}_{2}\right)$ has a positive coefficient of 0.171 . A positive regression coefficient value indicates that access to capital $\left(\mathrm{X}_{2}\right)$ has a positive effect on the performance of MSMEs (Y). this illustrates that every increase in 1 unit of access to capital $\left(\mathrm{X}_{2}\right)$ can increase the performance of MSMEs (Y) by 0.171 .

4. The variable of interest in using e-commerce $\left(\mathrm{X}_{3}\right)$ has a positive coefficient of 0.176 . A positive regression coefficient value indicates that interest in using ecommerce $\left(\mathrm{X}_{3}\right)$ positively affects MSME performance $(\mathrm{Y})$. this illustrates that every 1 unit increase in interest in using e-commerce $\left(\mathrm{X}_{3}\right)$ can increase the performance of MSMEs (Y) by 0.176 .

5. The innovation variable $\left(\mathrm{X}_{4}\right)$ has a positive coefficient of 0.025 . A positive regression coefficient value indicates that Innovation $\left(\mathrm{X}_{4}\right)$ has a positive effect on the performance of MSMEs (Y). this illustrates that every increase in 1 unit of innovation $\left(\mathrm{X}_{4}\right)$ can increase the performance of SMEs $(\mathrm{Y})$ by 0.176 .

The coefficient of determination shows how much influence the independent variable has on the dependent variable, which is indicated by the Adjusted R Square value. The following are the results of the coefficient of determination test, which are presented in table 4.

Table 4. Coefficient of Determination Test Results

\begin{tabular}{|c|c|c|c|c|c|c|}
\hline \multirow[t]{2}{*}{ I } & \multirow[t]{2}{*}{ Model } & \multicolumn{2}{|c|}{$\begin{array}{c}\text { Unstandardized } \\
\text { Coefficients }\end{array}$} & \multirow{2}{*}{$\begin{array}{c}\begin{array}{c}\text { Standardized } \\
\text { Coefficients }\end{array} \\
\text { Beta }\end{array}$} & \multirow{2}{*}{$\mathrm{t}$} & \multirow{2}{*}{ Sig. } \\
\hline & & $\mathrm{t}$ & $\begin{array}{l}\text { Std. } \\
\text { Error }\end{array}$ & & & \\
\hline \multirow{5}{*}{1} & (Constant) & 1,822 & ,910 & & 2,004 & ,233 \\
\hline & (X1) &, 056 &, 025 & 163 & 2,220 & ,028 \\
\hline & $(\mathrm{X} 2)$ &, 171 & ,035 & ,345 & 4,871 & ,000 \\
\hline & (X3) &, 176 & , 110 & ,349 & 1,549 & ,023 \\
\hline & (X4) & ,025 & ,114 & ,050 & 4,217 & ,045 \\
\hline
\end{tabular}

Based on table 4, it is known that the calculation of the coefficient of determination is 0.407. This shows that $40.7 \%$ of MSME performance variables are influenced by financial literacy variables, access to capital, interest in using e-commerce and innovation. In comparison, $59.3 \%$ are influenced by other factors such as empowerment, social capital, business networks, and other variables. Outside of this research.

\subsection{The Effect of Financial Literacy on MSME Performance}

Financial literacy has a positive and significant effect on the performance of MSMEs in the Buleleng District. Based on [27] opinion, financial literacy is the knowledge that includes all of the concepts of finance, 
personal/company financial management and the ability to make financial decisions in certain situations, both personal finance and business finance. The results of this study are by the Attribution Theory [28], which explains the internal and external factors that affect a person; in this case, financial literacy is an internal factor. Financial literacy is very important for MSME business actors in Buleleng District because it can help in improving business performance, such as knowledge in managing business finances. They know how to manage finances and make financial decisions in their business. The high level of financial literacy will affect MSME business actors in optimizing their business performance and being careful in carrying out their operations.

The results of this study are consistent by the results of research conducted by [29][30]. Financial literacy owned by business actors will help improve their performance in financial planning to maximize the time value of money. Financial literacy will optimize business performance carefully so that they have good financial skills and knowledge. It will make it easier to manage their business and assist in making financial decisions in their business.

A similar study was also conducted by [31], which showed a positive and significant influence of financial literacy on the performance of MSMEs. Business actors will also optimize their business performance and be more careful in making financial decisions on their business and making it easier to manage their business. However, in this case, some researchers have research results that contradict the results of this study, namely research conducted [32].

\subsection{The Effect of Access to Capital on MSME Performance}

Based on the data analysis, the second hypothesis $\left(\mathrm{H}_{2}\right)$ in this study is accepted, which indicates that access to capital has a positive and significant effect on the performance of MSMEs. The easier access to capital obtained by MSME business actors, the better the performance of MSME business actors. Access to capital is the most important component for a business because it helps MSME actors to advance their business, such as product diversification and business expansion. Information regarding access to capital provided by financial institutions, whether it is information on credit granting procedures, ease of accessing credit and credit terms, and other information related to accessing capital, is very important and can help MSME business actors develop their businesses.

This is also by the theory [33], which states that the ease of accessing capital affects improving the performance of MSMEs because MSME business actors are given the convenience of accessing capital. In addition, [34] says that access to money, such as lending by financial institutions, both banks and non-banks, is aimed at helping MSME business actors in business expansion and sustainability in the future. The ease of accessing capital is very helpful for MSME business actors in Buleleng District to increase income, business continuity and sustainability of MSME business actors. The results in line with [35].

\subsection{The Effect of Interest in Using $E$ - commerce on MSME Performance}

The third hypothesis $\left(\mathrm{H}_{3}\right)$ in this study was accepted. Where the interest in using e-commerce has a positive and significant effect on the performance of MSMEs, if the interest in using e-commerce in MSME business actors is high, then MSME performance will also be better. Based on the theory of [36], the results of this study are also supported by Attribution Theory which states that interest in using e-commerce is an internal factor that can affect the performance of MSMEs. Interest in using e-commerce is an internal factor in MSME business actors if MSME business actors have a high interest in using e-commerce. The use of e-commerce for MSME business actors will also be able to help MSME business actors to increase income because e-commerce makes it easier for MSME business actors to carry out business activities and find potential customers.

The use of e-commerce in conducting a transaction for MSMEs, be it sales, purchases, or other dealings, can increase business income. Interest in using e-commerce among MSME business actors arises because of the perception of convenience. [37] stated that ease of use is the degree to which a person believes that technology is easy to understand; if MSME business actors think that e-commerce can help business actors facilitate business activities, then the interest of MSME business actors will also increase. It will be higher so that MSME business actors will use e-commerce in their business activities to facilitate business activities, improve performance and increase business income.

\subsection{The Effect of Innovation on MSME Performance}

The ability to innovate from MSME business actors will create new business opportunities and impact business performance and help increase the income of MSME business actors in Buleleng District. Through innovation owned by businesses, actors can help in developing their products and sustainability in the future. In addition, innovation will impact the performance of the MSME itself as it will impact business development because the business that is run is not monotonous and has breakthroughs. Consumers will look for products that suit current needs. The company must continue to innovate in its industry. In addition, innovation will make it easier for business actors to expand market share and 
increase customer loyalty because products are increasingly varied. Business efficiency and effectiveness can be improved.

\section{CONCLUSION}

Interest in using e-commerce has a very large influence on the performance of MSMEs in Buleleng District because it is one of the impetus for MSME business actors to increase their business income; in addition to e-commerce, business actors can expand their business network to distribute products and sell their products. Besides, it helps business actors to establish communication with customers or consumers which then helps increase income. This research has implications so that in the future, MSME business actors will be easier to access capital because it will help them develop their businesses and can help increase income. This statement is by the theory of [33] the performance of MSMEs in Buleleng District.

\section{REFERENCES}

[1] A. Purwanto, "Potret dan Tantangan UMKM di Indonesia," Kompaspedia.kompas.id, Jakarta, p. 1, Sep. 2020.

[2] Kementerian PPN/Bappenas, "Penguatan UMKM untuk Pertumbuhan Ekonomi yang Berkualitas," War. KUMKM, vol. 5, no. 1, pp. 136, 2016, doi: https://www.bappenas.go.id/files/8014/8116/67 53/Warta_KUMKM_2016_Vol_5_No_1.pdf.

[3] Badan Pusat Statistik, Potensi Peningkatan Kinerja Usaha Mikro Kecil. 2019.

[4] L. Xu and B. Zia, "Financial Literacy around the World An Overview of the Evidence with Practical Suggestions for the Way Forward," 2012.

[5] Ira, "19.000 UMKM Buleleng Mampu Akses KUR,” Bisnis Bali, Buleleng, p. 1, 2019.

[6] U. Umamah, N. T. Herawati, and I. G. A. Purnamawati, "Analisis Perbedaan Penerapan Akuntansi Dilihat Dari Kategori Gender, Omzet Usaha Dan Literasi Keuangan Pada Usaha Mikro Kecil Dan Menengah (Studi Kasus UMKM Kecamatan Buleleng)," JIMAT (Jurnal Ilm. Mhs. Akunt. S1), vol. 10, no. 1, 2019.

[7] R. Purwaningsih and D. Kusuma, "Analisis Faktor-faktor Yang Mempengaruhi Kinerja Usaha Kecil Menengah (UKM) Dengan Metode Structural Equation Modeling Studi Kasus UKM berbasis Industri Kreatif Kota Semarang," J. Ilm., vol. 1, no. 1, pp. 7-12, 2015.
[8] Badan Pusat Statistik Provinsi Bali, "Banyaknya Tenaga Kerja menurut Kabupaten/Kota dan Skala Usaha Hasil Sensus Ekonomi 2016,” 2019.

[9] R. L. J. A. Vidal, R. Chiva, "A Measurement Scale for Product Innovation Performance," Eur J. Innov. Manag, vol. 9, no. 4, pp. 333-346, 2006.

[10] E. Agbor, "Creativity and Innovation," $J$. Strateg. Leadersh., vol. 1, no. 1, pp. 39-45, 2008.

[11] H. G. L. Prasetya, "Membangun Keunggulan Kompetitif Melalui Aliansi Stratejik Untuk Meningkatkan Kinerja Perusahaan (Studi Kasus Pada PT. Pos Indonesia Wilayah VI Jateng dan DIY)," Universitas Diponegoro, 2008.

[12] Porter, Competitive Strategy: Techniques For Analyzing Industries and Competitors. Free Press, 1992.

[13] Hasyim and S. P. Lestari, "Determinan Keunggulan Bersaing Berkelanjutan UKM Binaan FEDEP (Forum Economic Development And Employment Promotion) Kota Semarang," Serat Acitya - J. Ilm. UNTAG Semarang, vol. 6, no. 1, pp. 102-110, 2017.

[14] K. . Larasati, Pengaruh Literasi Keuangan, Kompetensi Sumber Daya Manusia dan Modal Usaha Terhadap Kinerja UMKM di Surabaya. Surabaya, 2018.

[15] S. Ariani, P. A. A. A. Rahmah, Y. R. Putri, M. Rohmah, A. Budiningrum, and Lutfi, "Pengaruh Literasi Keuangan, Locus of Control, dan Etnis terhadap Pengambilan Keputusan Investasi," $J$. Bus. Bank., vol. 5, no. 2, pp. 257-270, 2016, doi: 10.14414/jbb.v5i2.706.

[16] A. Sulistiogo, "Kinerja: UMKM Dampak Kualitas SDM dan Akses Informasi Terhadap Akses Permodalan," J. Din. Manaj. dan Bisnis, vol. 2, no. 1, pp. 65-76, 2019.

[17] F. Heider, The Psychology of Interpersonal Relations. New York: Wiley, 1958.

[18] M. Porter, Competitive Strategy. New York: Free Press, 1988.

[19] A. Zait and P. E. Bertea, "Financial Literacy Conceptual Definition and Proposed Approach for a Measurement Instrument," J. Account. Manag., vol. 4, no. 3, pp. 37-42, 2014.

[20] C. T. Widiastuti, "Model Manajemen EduFinance Untuk Meningkatkan Literasi Keuangan Pada Umkm Kayu Kota Semarang," J. Bisnis dan 
Ekon., vol. 24, no. 2, pp. 112-118, 2017.

[21] A. Lusardi, "Numeracy, Financial Literacy, and Financial Decision-Making," Cambridge, UK, 17821, 2012.

[22] Nkundabanyanga, "Lending Terms, Financial Literacy and Formal Credit Accessibility," Int. J. Soc. Econ., vol. 41, no. 5, pp. 342-361, 2013.

[23] Lusimbo and Muturi, "Financial Literacy And The Growth Of Small Enterprises In Kenya: A Case Of Kakamega Central Sub- County, Kenya," Int. J. Econ. Commer. Manag., vol. 4, no. 6, pp. 828-845, 2016.

[24] M. A. Darmayanti, N. P., Purnamwati, I. A., \& Prayudi, "Pengaruh Pendekatan TeChnology Acceptance Model dan Faktor Sosial Terhadap Penerapan Sistem Informasi Keuangan Daerah Pada SKPD di Kabupaten Gianyar," e-Journal S1 Ak Univ. Pendidik. Ganesha, vol. 8, no. 2, pp. 1-12, 2017.

[25] P. Kotler and G. Amstrong, Principles of Marketing, 15th ed. England: Pearson Prentice Hall, 2018.

[26] M. Nazir, Metode Penelitian: Edisi Pertama. Jakarta: Ghalia Indonesia, 2003.

[27] P. Dahmen and E. Rodríguez, "Financial Literacy and the Success of Small Businesses: An Observation from a Small Business Development Center," Numeracy, vol. 7, no. 1, pp. 1-12, 2014, doi: 10.5038/1936-4660.7.1.3.

[28] I. G. A. Purnamawati and G. A. Yuniarta, "Women and Strategic Dimensions in Acceleration of Poverty Reduction," Manag. Sci. Lett., vol. 10, no. 15, pp. 3587-3596, 2020, doi: 10.5267/j.msl.2020.6.035.

[29] K. M. Usama and W. F. W. Yusoff, "The Relationship Between Entrepreneurs' Financial Literacy and Business Performance Among Entrepreneurs Of Bauchi State Nigeria," Int. J. Entrep. Bus. Innov., vol. 1, no. 1, pp. 15-26, 2018.

[30] K. M. Usama and W. F. W. Yusoff, "The Impact of Financial Literacy on Business Performance," Int. J. Res. Innov. Soc. Sci., vol. 3, no. 10, pp. 8491, 2019.

[31] R. Barte, "Financial Literacy in Micro-Enterprises: The Case of Cebu Fish Vendors," Philipp. Manag. Rev., vol. 19, p. 9199, 2012.
[32] K. D. Larasati, "Pengaruh Literasi Keuangan, Kompetensi Sumber Daya Manusia dan Modal Usaha Terhadap Kinerja UMKM di Surabaya," Sekolah Tinggi Ilmu PERBANAS, Surabaya, 2018.

[33] A. Rauch, G. T. Lumpkin, J. Wiklund, and M. Frese, "Entrepreneurial Orientation and Business Performance: An Assessment of Past Research and Suggestions for the Future," Entrep. Theory Pract., vol. 33, no. 3, pp. 761-787, 2009, doi: 10.1111/j.1540-6520.2009.00308.x.

[34] P. I. C. Putra and I. G. A. Purnamawati, "Prosedur Pemberian Kredit Usaha Mikro Dan Menengah Pada PT Pegadaian Cabang Singaraja," JIMAT (Jurnal Ilm. Mhs. Akuntansi), vol. 11, no. 2, pp. 191-202, 2020.

[35] A. D. Buchdadi, A. Sholeha, G. N. Ahmad, and Mukson, "The Influence Of Financial Literacy On SMEs Performance Through Access To Finance And Financial Risk Attitude As Mediation Variables," Acad. Account. Financ. Stud. J., vol. 24, no. 5, pp. 1-16, 2020.

[36] K. Philip and G. Amstrong, Principles Of Marketing, Global Edition, 14th ed. Pearson Education, 2012.

[37] P. Novalia, I. G. A. Purnamawati, and M. A. Wahyuni, "Pengaruh Persepsi Kebermanfaatan, Kemudahan, Dan Kepuasan Wajib Pajak Orang Pribadi Terhadap Penggunaan E-Billing," JIMAT (Jurnal Ilm. Mhs. Akuntansi), vol. 10, no. 2, pp. 218-229, 2019. 